\title{
The Contribution of Gene Mutations to the Pathogenesis of Tetralogy of Fallot
}

\author{
Amin Safari-Arababadi ${ }^{1,2}$, Mostafa Behjati-Ardakani ${ }^{3 *}$, Seyed Mehdi Kalantar ${ }^{4}$, Mojtaba Jaafarinia ${ }^{1,2}$ \\ 'Department of Molecular Genetics, Fars Science and Research Branch, Islamic Azad University, Shiraz, Iran \\ ${ }^{2}$ Department of Molecular Genetics, Marvdasht Branch, Islamic Azad University, Marvdasht, Iran \\ ${ }^{3}$ Yazd Cardiovascular Research Center, Shahid Sadoughi University of Medical Sciences, Yazd, Iran \\ ${ }^{4}$ Genetic and Reproductive Unit, Recurrent Abortion Research Centre, Yazd Reproductive Sciences Institute, Shahid \\ Sadoughi University of Medical Sciences, Yazd, Iran
}

\section{*Correspondence to Mostafa Behjati-Ardakani, Yazd Cardiovascular Research Center, Shahid Sadoughi University of Medical Sciences, Yazd, Iran. Tel/Fax: +989131514821 Email: dr_behjati@Genomix.ir}

Received May 16, 2019 Accepted June 23, 2019 Published online June 30, 2019

Please cite this article as follows: Safari-Arababadi A, Behjati-Ardakani M, Kalantar SM, Jaafarinia M. The contribution of gene mutations to the pathogenesis of tetralogy of Fallot. Int J Basic Sci Med. 2019;4(2):4550. doi:10.15171/ ijbms.2019.10.

\begin{abstract}
Congenital heart disease (CHD) is considered as an important and developing area in the medical community. Since these patients can reach maturity and have children, the role of genetic determinants in increasing risk of CHD is extremely evident among children of these patients. Because genetic studies related to CHD are increasing, and each day the role of new genetic markers is more and more clarified, this review re-examined the effects of gene mutations in the pathogenesis of tetralogy of Fallot (TOF) as an important pathological model among other CHDs. Due to the complexity of heart development, it is not astonishing that numerous signaling pathways and transcription factors, and many genes are involved in pathogenesis of TOF. This review focuses on the jag 1, nkx2.5, gata4, zfpm $2 / f \circ g 2$ and cited2 genes previously reported to be involved in TOF.

Keywords: Congenital heart disease, Tetralogy of Fallot, Gene mutation
\end{abstract}

patients, syndromic and non-syndromic. TOF has been observed in the context of several syndromes including Alagille syndrome (AGS), Trisomy 21, CHARGE (coloboma, heart, atresia of the nasal, retarded, genital, ear abnormalities) and DiGeorge syndromes. Nearly $20 \%$ of TOF cases are related to genetic syndromes. ${ }^{1,4,5}$ The presence of mutations in genes Jagged 1 (JAG1), NK2 Homeobox 5 (NKX2.5), binding protein GATA (GATA), zinc finger protein, FOG family member 2 (ZFPM2/FOG2), Cbp/p300-interacting transactivator with Glu/Asprich carboxyterminal domain 2 (CITED2) and variants of other genes and the interaction between genetic and environmental factors underly the pathogenesis of TOF. ${ }^{6-8}$ Therefore, this review addresses current information regarding the roles of variations in JAG1, NKX2.5, GATA4, ZFPM2/FOG2 and CITED2 genes in the pathogenesis of TOF.

(C) 2019 The Author(s); Published by Zabol University of Medical Sciences. This is an open-access article distributed under the terms of the Creative Commons Attribution License (http://creativecommons.org/licenses/by/4.0), which permits unrestricted use, distribution, and reproduction in any medium, provided the original work is properly cited. 


\section{JAG1}

The JAG1 gene is an embryological signaling molecule associated with cardiac development. ${ }^{9}$ JAG1 is a very important ligand that plays a substantial role in the developmental stages of the mammals' heart. De novo mutations in the JAG1 ligand of transmembrane receptors NOTCH1, NOTCH2 and themselves, are impressive in cardiac development that are involved in isolated TOF (Figure 1). ${ }^{10-12}$ Jagged1 is a ligand for the NOTCH family receptors that is encoded by JAG1 gene. ${ }^{13}$ The $J A G 1$ is involved in the decision of the cell's fate in the early cardiac development through Notch signaling, and mutation in a number of proteins in the pathway is seen in many disorders. ${ }^{14,15}$ The JAG1 heterozygous mutations are responsible for AGS. ${ }^{16,17}$ The clinical significance of AGS lies within its cardiac structural defects and hepatic dysfunction. ${ }^{18}$ Mutations in JAG1 responsible for AGS are basically deletions and truncations resulting in haploinsufficiency. ${ }^{6}$ In addition, the mutated JAG1 protein works as NOTCH signaling inhibitor. ${ }^{19}$ Conversely, population analysis of TOF patients mainly detects missense mutations that produce functional mRNA and a non-functional protein which prevents proper passage in the nuclear membrane due to the effect on posttranslational properties. Specifically, TOF patients and carrier parents who had no apparent clinical symptoms showed an increased risk of TOF in next generations. ${ }^{8,20}$ The JAG1 structural and functional studies have shown that this gene is involved in stem cell maintenance, cell fate, cell growth, several malignancies, tumor angiogenesis, and metastatic behavior in brain, breast, head/neck, ovarian, prostate, kidney, colorectal, gastric, cervical, endometrial, pancreatic, hepatic, adrenocortical and lung cancers. ${ }^{21-24}$ The tumor invasion is affected by the relative concentration of JAG1 mRNA and is linked to the patient survival. ${ }^{21,22}$ JAG1 mutations were first identified in TOF and $\mathrm{CHD}$ patients with pulmonary stenosis. ${ }^{6}$ Among the Notch ligands, exon 6 of the JAG1 gene is more conserved than other exons. ${ }^{11,25}$ Several significant mutations have been identified in exon 6 that are associated with TOF. The missense mutation of G274D was reported in 2001 by Eldadah et al. ${ }^{1}$ This mutation was also identified in TOF patients in a study in 2009 but was not seen in patients with AGS syndrome. ${ }^{26}$ In a study by Kola et al, 4 novel variations in exon 6, including 2 missense (E278D and $\mathrm{V} 272 \mathrm{~F}), 1$ nonsense (Y255X) and 1 silent variation $(\mathrm{N} 287 \mathrm{~N})$ were reported in TOF patients. ${ }^{27}$ In a recent study in Iran, Safari-Arababadi et al, reported a significant association between synonymous variant Y255Y and TOF in Iranians. ${ }^{28}$

\section{NKX2.5}

NKX2.5 is an essential transcription factor for the development, myogenesis, and function of the heart in the fetus. ${ }^{29}$ The homologous of NKX2.5 gene in Drosophila is tinman gene. When this gene is knocked

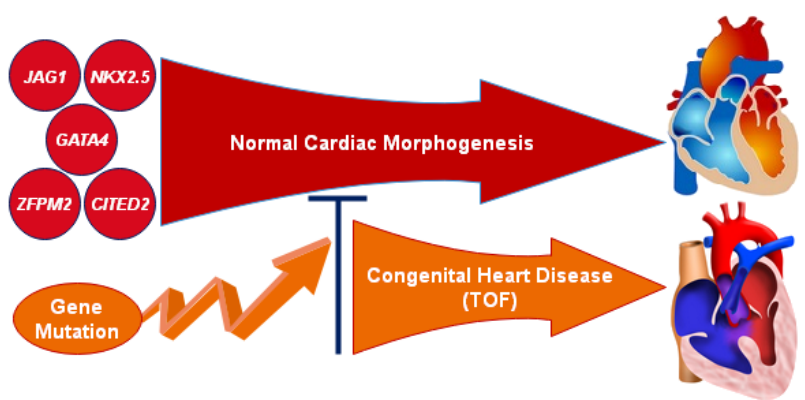

Figure 1. Gene Mutations Involved in the Tetralogy of Fallot. Gene mutations occur in the genes responsible for the normal morphogenesis of the heart, causing congenital heart disease such as tetralogy of Fallot.

out in the Drosophila, the development of the heart is also impaired. ${ }^{30-33}$ In the development and formation of the heart, the association of NKX2.5 with septal defects is very impressive as a major feature of TOF. ${ }^{34}$ NKX2.5 mutations lead to various types of cardiac abnormalities and could account for a major proportion of the idiopathic atrioventricular block and TOF. ${ }^{34}$ In different forms of CHD, including atrial septal defect (ASD), VSD and TOF, over 37 mutations have been reported to be associated with the NKX2.5. ${ }^{35,36}$ Mutations related to TOF rarely belong to the homeodomain region of the gene, but often result in substitutions of extremely conserved amino acids. While these mutations do not lead to a relative change in the expression of proteins, substitutions in these extremely conserved domains affect the interactions with other molecules, such as DNA, and the downstream function. ${ }^{37}$ Therefore, the NKX2.5 related mutations that produce truncated and structurallyaltered proteins are distinct. ${ }^{38-40}$ There is a homeodomain region called 60 -amino acid in the NKX2.5 protein, which is a helix-turn-helix motif that contains $3 a$-helices and interacts with DNA. This is the most important role of NKX2.5 as a transcription factor. ${ }^{41,42}$ In patients with TOF, there is an association between NKX2.5 methylation and transcriptional regulation, which seems to play a significant role in TOF pathogenesis. ${ }^{43}$

To identify the clinical effects of NKX2.5 mutations associated with TOF, it is necessary to study large populations of patients. However, despite these limitations, significant clinical features related to NKX2.5 mutations have been identified. ${ }^{44}$ Research has shown that 2 causes of death in TOF patients are arrhythmias and sudden cardiac death, and the only clinical symptom to predict these complications is prolonged QRS complex (QRS duration $\geq 180 \mathrm{~ms}$ ). ${ }^{45-51}$ It is assumed that these clinical symptoms can be related to the NKX2.5 gene, but no study has yet been conducted on the association of NKX2.5 mutations with these symptoms. NKX2.5 plays an outstanding role in the development of normal conduction pathways. Mutations in this gene may disrupt this pathway and cause abnormalities, which can be verified by genetic 
research in the future. ${ }^{34,38,52}$ Therefore, it will be better to study NKX2.5 associated TOF patients with long-term clinical symptoms in the future. In Iran, Kheirrollahi et al studied the association between NKX2.5 gene and TOF, and only one synonymous variant was seen in the patients. Therefore, there was no significant association between this gene and TOF in Iranian patients. ${ }^{53}$

\section{GATA4}

The complex process of development of the embryonic heart requires the collaboration of processes such as differentiation, cell fate, reproduction, migration and apoptosis. ${ }^{54}$ Furthermore, cardiac transcription factors including the GATA family are involved in this process. ${ }^{55,56}$ These transcription factors include a family of DNA binding proteins with zinc finger domains that bind to DNA. In the vertebrate, 6 GATA families have been identified (i.e. GATA1-GATA6), among which GATA4, GATA5 and GATA6 are primarily expressed in the fetal heart. Among these 3 factors, GATA4 plays a vital role in regulating gene expression in heart development and function. ${ }^{56}$ In patients with a variety of congenital cardiovascular diseases, including TOF, many GATA4 gene mutations are involved..$^{57-60}$ In a recent research in China, 3 families with autosomal dominant mutations in the GATA4 gene have been identified. ${ }^{61}$ These mutations occurred in 2-3 generations in each family, and the function of the transcription factor and DNA binding capacity also decreased. Furthermore, the mutations disturbed the physical interaction of GATA4 with TBX5, which is an effective signaling molecule in the cardiac development. ${ }^{61,62}$ In addition to GATA4 mutations in familial TOF, these mutations have also been present in sporadic pediatric cases in Chinese CHD patients. ${ }^{63}$ However, further research is required in order to confirm the role of GATA4 mutations in sporadic non-syndromic TOF to determine whether these mutilations are linked to TOF in Asian populations as Asia has the highest prevalence of TOF. $^{64}$

\section{ZFPM2/FOG2}

ZFPM2 gene (formerly known as FOG2) encodes a zincfinger transcription cofactor called FOG2 (friend of GATA). This protein is a regulator of the GATA4 that can be involved in the pathogenesis of TOF via GATA4. ${ }^{59,65,66}$ In mice, the ZFPM2 gene plays an important role in the development of the heart as well as in the normal testis development. However, no effect on gonadal function has been observed in humans. ${ }^{67}$ ZFPM2-knockout mice displayed cardiac malformations, which were similar to the symptoms of TOF in humans causing embryonic death. ${ }^{68}$ ZFPM2 mutations can cause CHD by interfering with GATA4 or the NuRD (nucleosome remodeling and deacetylation) complex. ${ }^{69}$ Many studies have shown that there is a significant relationship between ZFPM2 gene mutations and TOF. Pizzuti et al in Italy identified 2 missense mutations, E30G and S657G, in TOF patients. Both mutations alter amino acid residues that are conserved between mouse and human ZFPM2 sequences. ${ }^{65}$ In another study in Italy, De Luca et al reported a novel missense mutation, M544I, in the ZFPM2 associated with TOF. $^{70}$ In 2014, Zhang et al found 2 missense variants including M703L and a novel variant T843M in Chinese patients with $\mathrm{TOF}^{71}$ At the same time, Huang et al in China detected missense variants, A2107C and C1208G as well as 2 novel variants, G2482A and G1552A, in TOF patients. They also suggested that ZFPM2 mutations could be used as potential biomarkers and for therapeutic purposes in patients with TOF. ${ }^{72}$ In another study in China, Qian et al found 2 missense variants including E1005G and a novel variant, E1148K, in patients with TOF. The E1148K is conserved in various species located on the eighth Zincfinger domain, and may participate in the pathogenesis of TOF via destruction of the interaction with GATA4. ${ }^{73}$

\section{CITED2}

CITED2 gene plays a significant role in the development of the heart, and mutations in this gene are potential risk factors for CHD including the TOF ${ }^{74,75}$ The CITED2 is the most important member of the CITED gene family, and the protein sequence of this gene has been coded by the 3 conserved regions (CR1, CR2 and CR3). ${ }^{76}$ CITED2 as a cAMP-response element binding protein (CREB) interacts with transcriptional modulator and is suggested as a negative regulator for hypoxia-inducible factor $1 a$ (HIF-1a). HIF-1a is a major transcription factor that is needed for cardiovascular development and CITED2 mutations cause overexpression of HIF- $1 \alpha{ }^{76,77}$ Springer et al in a cohort study in Germany reported for the first time 2 mutations in this gene, namely, c.-91G>A and c. $1268 \mathrm{~A}>\mathrm{G}$, in patients with $\mathrm{TOF}^{74}$ CITED2 gene mutations that cause loss of function result in impaired cardiac development by altering the expression of genes such as vascular endothelial growth factor (VEGF) and paired-like homeodomain transcription factor 2-gamma (PITX2C). ${ }^{75,78}$ In 3 studies in 2010, 2012 and 2014 in China, missense mutation of G184S in the CITED2 was observed in patients with TOF $^{75,76,79}$ Liu et al in 2014 observed the P140S mutation of CITED2 gene in Chinese patients with TOF. ${ }^{80}$ These mutations affect the expressions of PITX2C and VEGF genes, both of which play an extremely important role in the development of the heart (Figure 2)..$^{75,80}$

\section{Conclusion}

Many articles and reviews have focused on the role of gene mutations in CHD patients. Further, very few genetic studies have been conducted on TOF patients and the role of gene mutations in the development of TOF in Iranians. The purpose of this review was to provide an overview on highly significant genes that may be involved in the pathogenesis of TOF. The disturbance of balance 


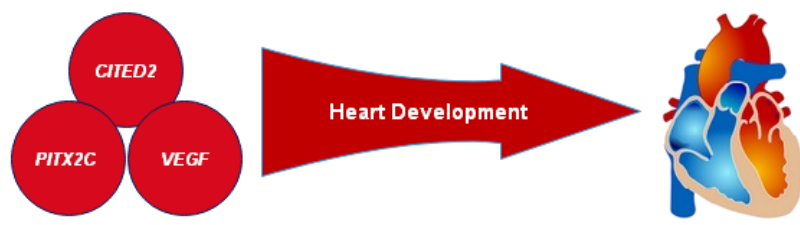

Figure 2. Interaction of the CITED2 With Other Genes on the Development of the Heart; the CITED2 gene, with the help of the VEGF and PITX2C genes, plays a very important role in the development of the heart.

between transcription factors plays a substantial role in the development of the heart in the pathogenesis of nonsyndromic TOF. Studies have not yet been conducted to assess the impacts of gene mutations on mortality and morbidity rates in TOF. As most patients with TOF reach reproductive age, genetic studies in TOF patients and genetic counseling can play a very important role in managing TOF.

\section{Ethical Issues \\ Not applicable.}

\section{Conflict of Interests}

Authors declare that they have no competing interests.

\section{Financial Support \\ Not applicable.}

\section{Acknowledgements}

The authors thank all who have contributed to the preparation of this manuscript.

\section{References}

1. Eldadah ZA, Hamosh A, Biery NJ, et al. Familial Tetralogy of Fallot caused by mutation in the jagged 1 gene. Hum Mol Genet. 2001;10(2):163-169. doi:10.1093/hmg/10.2.163

2. Apitz C, Webb GD, Redington AN. Tetralogy of fallot. Lancet. 2009;374(9699):1462-1471. doi:10.1016/s01406736(09)60657-7

3. Di Felice V, Zummo G. Tetralogy of fallot as a model to study cardiac progenitor cell migration and differentiation during heart development. Trends Cardiovasc Med. 2009;19(4):130-135. doi:10.1016/j.tcm.2009.07.004

4. Kutiyanawala M, Wyse RK, Brereton RJ, et al. CHARGE and esophageal atresia. J Pediatr Surg. 1992;27(5):558-560. doi:10.1016/0022-3468(92)90445-d

5. Marino B, Digilio MC, Grazioli S, et al. Associated cardiac anomalies in isolated and syndromic patients with tetralogy of Fallot. Am J Cardiol. 1996;77(7):505-508. doi:10.1016/ s0002-9149(97)89345-9

6. Krantz ID, Smith R, Colliton RP, et al. Jagged 1 mutations in patients ascertained with isolated congenital heart defects. Am J Med Genet. 1999;84(1):56-60. doi:10.1002/(sici)10968628(19990507)84:1<56::aid-ajmg11>3.0.co;2-w

7. Le Caignec C, Lefevre M, Schott JJ, et al. Familial deafness, congenital heart defects, and posterior embryotoxon caused by cysteine substitution in the first epidermalgrowth-factor-like domain of jagged 1. Am J Hum Genet. 2002;71(1):180-186. doi:10.1086/341327

8. Lu F, Morrissette JJ, Spinner NB. Conditional JAG1 mutation shows the developing heart is more sensitive than developing liver to JAG1 dosage. Am J Hum Genet. 2003;72(4):1065-1070. doi:10.1086/374386

9. Grochowski CM, Loomes KM, Spinner NB. Jagged1 (JAG1): Structure, expression, and disease associations. Gene. 2016;576(1 Pt 3):381-384. doi:10.1016/j.gene.2015.10.065

10. Botto LD, Khoury MJ, Mulinare J, Erickson JD. Periconceptional multivitamin use and the occurrence of conotruncal heart defects: results from a population-based, case-control study. Pediatrics. 1996;98(5):911-917.

11. Cordle J, Johnson S, Tay JZ, et al. A conserved face of the Jagged/Serrate DSL domain is involved in Notch trans-activation and cis-inhibition. Nat Struct Mol Biol. 2008;15(8):849-857. doi:10.1038/nsmb.1457

12. Rauch R, Hofbeck M, Zweier C, et al. Comprehensive genotype-phenotype analysis in 230 patients with tetralogy of Fallot. J Med Genet. 2010;47(5):321-331. doi:10.1136/ jmg.2009.070391

13. Guegan K, Stals K, Day M, Turnpenny P, Ellard S. JAG1 mutations are found in approximately one third of patients presenting with only one or two clinical features of Alagille syndrome. Clin Genet. 2012;82(1):33-40. doi:10.1111/ j.1399-0004.2011.01749.x

14. Artavanis-Tsakonas S, Rand MD, Lake RJ. Notch signaling: cell fate control and signal integration in development. Science. 1999;284(5415):770-776. doi:10.1126/ science.284.5415.770

15. Ehebauer M, Hayward P, Arias AM. Notch, a universal arbiter of cell fate decisions. Science. 2006;314(5804):14141415. doi:10.1126/science. 1134042

16. Li L, Krantz ID, Deng Y, et al. Alagille syndrome is caused by mutations in human Jagged1, which encodes a ligand for Notch1. Nat Genet. 1997;16(3):243-251. doi:10.1038/ ng0797-243

17. McDaniell R, Warthen DM, Sanchez-Lara PA, et al. NOTCH2 mutations cause Alagille syndrome, a heterogeneous disorder of the notch signaling pathway. Am J Hum Genet. 2006;79(1):169-173. doi:10.1086/505332

18. Turnpenny PD, Ellard S. Alagille syndrome: pathogenesis, diagnosis and management. Eur J Hum Genet. 2012;20(3):251-257. doi:10.1038/ejhg.2011.181

19. Morrissette JD, Colliton RP, Spinner NB. Defective intracellular transport and processing of JAG1 missense mutations in Alagille syndrome. Hum Mol Genet. 2001;10(4):405-413. doi:10.1093/hmg/10.4.405

20. Bauer RC, Laney AO, Smith R, et al. Jagged1 (JAG1) mutations in patients with tetralogy of Fallot or pulmonic stenosis. Hum Mutat. 2010;31(5):594-601. doi:10.1002/ humu. 21231

21. Reedijk M, Odorcic S, Chang L, et al. High-level coexpression of JAG1 and NOTCH1 is observed in human breast cancer and is associated with poor overall survival. Cancer Res. 2005;65(18):8530-8537. doi:10.1158/00085472.can-05-1069

22. Dickson BC, Mulligan AM, Zhang $\mathrm{H}$, et al. High-level JAG1 mRNA and protein predict poor outcome in breast 
cancer. Mod Pathol. 2007;20(6):685-693. doi:10.1038/ modpathol.3800785

23. Li D, Masiero M, Banham AH, Harris AL. The notch ligand JAGGED1 as a target for anti-tumor therapy. Front Oncol. 2014;4:254. doi:10.3389/fonc.2014.00254

24. Simon DP, Giordano TJ, Hammer GD. Upregulated JAG1 enhances cell proliferation in adrenocortical carcinoma. Clin Cancer Res. 2012;18(9):2452-2464. doi:10.1158/10780432.ccr-11-2371

25. Pintar A, Guarnaccia C, Dhir S, Pongor S. Exon 6 of human JAG1 encodes a conserved structural unit. BMC Struct Biol. 2009;9:43. doi:10.1186/1472-6807-9-43

26. Guarnaccia C, Dhir S, Pintar A, Pongor S. The tetralogy of Fallot-associated G274D mutation impairs folding of the second epidermal growth factor repeat in Jagged-1. FEBS J. 2009;276(21):6247-6257. doi:10.1111/j.17424658.2009.07333.x

27. Kola S, Koneti NR, Golla JP, Akka J, Gundimeda SD, Mundluru HP. Mutational analysis of JAG1 gene in nonsyndromic tetralogy of Fallot children. Clin Chim Acta. 2011;412(23-24):2232-2236. doi:10.1016/j.cca.2011.08.017

28. Safari-Arababadi A, Behjati-Ardakani M, Kalantar SM, Jaafarinia M. Silencing mutations in JAG1 gene may play crucial roles in the pathogenesis of Tetralogy of Fallot. Cell Mol Biol (Noisy-le-grand). 2018;64(4):103-107.

29. Lyons I, Parsons LM, Hartley L, et al. Myogenic and morphogenetic defects in the heart tubes of murine embryos lacking the homeo box gene Nkx2-5. Genes Dev. 1995;9(13):1654-1666. doi:10.1101/gad.9.13.1654

30. Tanaka M, Schinke M, Liao HS, Yamasaki N, Izumo S. Nkx2.5 and Nkx2.6, homologs of Drosophila tinman, are required for development of the pharynx. Mol Cell Biol. 2001;21(13):4391-4398. doi:10.1128/mcb.21.13.43914398.2001

31. Bodmer R. The gene tinman is required for specification of the heart and visceral muscles in Drosophila. Development. 1993;118(3):719-729.

32. Shiojima I, Komuro I, Mizuno T, et al. Molecular cloning and characterization of human cardiac homeobox gene CSX1. Circ Res. 1996;79(5):920-929. doi:10.1161/01. res.79.5.920

33. Evans SM. Vertebrate tinman homologues and cardiac differentiation. Semin Cell Dev Biol. 1999;10(1):73-83. doi:10.1006/scdb.1999.0282

34. Benson DW, Silberbach GM, Kavanaugh-McHugh A, et al. Mutations in the cardiac transcription factor NKX2.5 affect diverse cardiac developmental pathways. J Clin Invest. 1999;104(11):1567-1573. doi:10.1172/jci8154

35. Xiong F, Li Q, Zhang C, et al. Analyses of GATA4, NKX2.5, and TFAP2B genes in subjects from southern China with sporadic congenital heart disease. Cardiovasc Pathol. 2013;22(2):141-145. doi:10.1016/j.carpath.2012.07.001

36. Cao Y, Lan W, Li Y, Wei C, Zou H, Jiang L. Single nucleotide polymorphism of NKX2-5 gene with sporadic congenital heart disease in Chinese Bai population. Int J Clin Exp Pathol. 2015;8(11):14917-14924.

37. Gurvitz M, Ionescu-Ittu R, Guo L, et al. Prevalence of cancer in adults with congenital heart disease compared with the general population. Am J Cardiol. 2016;118(11):17421750. doi:10.1016/j.amjcard.2016.08.057

38. McElhinney DB, Geiger E, Blinder J, Benson DW,
GoldmuntzE. NKX2.5 mutations in patients with congenital heart disease. J Am Coll Cardiol. 2003;42(9):1650-1655. doi:10.1016/j.jacc.2003.05.004

39. Schott JJ, Benson DW, Basson CT, et al. Congenital heart disease caused by mutations in the transcription factor NKX2-5. Science. 1998;281(5373):108-111. doi:10.1126/ science.281.5373.108

40. Pabst S, Wollnik B, Rohmann E, et al. A novel stop mutation truncating critical regions of the cardiac transcription factor NKX2-5 in a large family with autosomal-dominant inherited congenital heart disease. Clin Res Cardiol. 2008;97(1):39-42. doi:10.1007/s00392-007-0574-0

41. Reamon-Buettner SM, Sattlegger E, Ciribilli Y, Inga A, Wessel A, Borlak J. Transcriptional defect of an inherited NKX2-5 haplotype comprising a SNP, a nonsynonymous and a synonymous mutation, associated with human congenital heart disease. PLoS One. 2013;8(12):e83295. doi:10.1371/journal.pone.0083295

42. Bartlett H, Veenstra GJ, Weeks DL. Examining the cardiac NK-2 genes in early heart development. Pediatr Cardiol. 2010;31(3):335-341. doi:10.1007/s00246-009-9605-0

43. Sheng W, Qian Y, Wang H, et al. DNA methylation status of NKX2-5, GATA4 and HAND1 in patients with tetralogy of fallot. BMC Med Genomics. 2013;6:46. doi:10.1186/17558794-6-46

44. Der Kaloustian VM, Ratl H, Malouf J, et al. Tetralogy of Fallot with pulmonary atresia in siblings. Am J Med Genet. 1985;21(1):119-122. doi:10.1002/ajmg.1320210117

45. Khairy P, Aboulhosn J, Gurvitz MZ, et al. Arrhythmia burden in adults with surgically repaired tetralogy of Fallot: a multi-institutional study. Circulation. 2010;122(9):868875. doi:10.1161/circulationaha.109.928481

46. Gatzoulis MA, Balaji S, Webber SA, et al. Risk factors for arrhythmia and sudden cardiac death late after repair of tetralogy of Fallot: a multicentre study. Lancet. 2000;356(9234):975-981. doi:10.1016/s01406736(00)02714-8

47. de Torres-Alba F, Kaleschke G, Baumgartner H. Impact of percutaneous pulmonary valve implantation on the timing of reintervention for right ventricular outflow tract dysfunction. Rev Esp Cardiol (Engl Ed). 2018;71(10):838846. doi:10.1016/j.rec.2018.05.001

48. Khairy P, Harris L, Landzberg MJ, et al. Implantable cardioverter-defibrillators in tetralogy of Fallot. Circulation. 2008;117(3):363-370. doi:10.1161/ circulationaha.107.726372

49. Cuypers JA, Menting ME, Konings EE, et al. Unnatural historyoftetralogy of Fallot:prospectivefollow-up of 40 years after surgical correction. Circulation. 2014;130(22):19441953. doi:10.1161/circulationaha.114.009454

50. Khairy P. Ventricular arrhythmias and sudden cardiac death in adults with congenital heart disease. Heart. 2016;102(21):1703-1709. doi:10.1136/ heartjnl-2015-309069

51. Hernandez-Madrid A, Paul T, Abrams D, et al. Arrhythmias in congenital heart disease: a position paper of the European Heart Rhythm Association (EHRA), Association for European Paediatric and Congenital Cardiology (AEPC), and the European Society of Cardiology (ESC) Working Group on Grown-up Congenital heart disease, endorsed by HRS, PACES, APHRS, and SOLAECE. Europace. 
2018;20(11):1719-1753. doi:10.1093/europace/eux380

52. Chung IM, Rajakumar G. Genetics of congenital heart defects: the NKX2-5 gene, a key player. Genes (Basel). 2016;7(2). doi:10.3390/genes7020006

53. Kheirollahi M, Khosravi F, Ashouri S, Ahmadi A. Existence of mutations in the homeodomain-encoding region of NKX2.5 gene in Iranian patients with tetralogy of Fallot. J Res Med Sci. 2016;21:24. doi:10.4103/1735-1995.179893

54. Bruneau BG. The developmental genetics of congenital heart disease. Nature. 2008;451(7181):943-948. doi:10.1038/nature06801

55. Arimura T, Ishikawa T, Nunoda S, Kawai S, Kimura A. Dilated cardiomyopathy-associated BAG3 mutations impair Z-disc assembly and enhance sensitivity to apoptosis in cardiomyocytes. Hum Mutat. 2011;32(12):1481-1491. doi:10.1002/humu.21603

56. Pikkarainen S, Tokola H, Kerkela R, Ruskoaho H. GATA transcription factors in the developing and adult heart. Cardiovasc Res. 2004;63(2):196-207. doi:10.1016/j. cardiores.2004.03.025

57. Garg V, Kathiriya IS, Barnes R, et al. GATA4 mutations cause human congenital heart defects and reveal an interaction with TBX5. Nature. 2003;424(6947):443-447. doi:10.1038/nature01827

58. Rajagopal SK, Ma Q, Obler D, et al. Spectrum of heart disease associated with murine and human GATA4 mutation. J Mol Cell Cardiol. 2007;43(6):677-685. doi:10.1016/j.yjmcc.2007.06.004

59. Nemer G, Fadlalah F, Usta J, et al. A novel mutation in the GATA4 gene in patients with Tetralogy of Fallot. Hum Mutat. 2006;27(3):293-294. doi:10.1002/humu.9410

60. Tomita-Mitchell A, Maslen CL, Morris CD, Garg V, Goldmuntz E. GATA4 sequence variants in patients with congenital heart disease. J Med Genet. 2007;44(12):779783. doi:10.1136/jmg.2007.052183

61. Yang YQ, Gharibeh L, Li RG, et al. GATA4 loss-of-function mutations underlie familial tetralogy of fallot. Hum Mutat. 2013;34(12):1662-1671. doi:10.1002/humu.22434

62. Steimle JD, Moskowitz IP. TBX5: a key regulator of heart development. Curr Top Dev Biol. 2017;122:195-221. doi:10.1016/bs.ctdb.2016.08.008

63. Zhang W, Li X, Shen A, Jiao W, Guan X, Li Z. GATA4 mutations in 486 Chinese patients with congenital heart disease. Eur J Med Genet. 2008;51(6):527-535. doi:10.1016/j.ejmg.2008.06.005

64. van der Linde D, Konings EE, Slager MA, et al. Birth prevalence of congenital heart disease worldwide: a systematic review and meta-analysis. J Am Coll Cardiol. 2011;58(21):2241-2247. doi:10.1016/j.jacc.2011.08.025

65. Pizzuti A, Sarkozy A, Newton AL, et al. Mutations of ZFPM2/FOG2 gene in sporadic cases of tetralogy of Fallot. Hum Mutat. 2003;22(5):372-377. doi:10.1002/humu.10261

66. Kobayashi M, Nishikawa K, Yamamoto M. Hematopoietic regulatory domain of gatal gene is positively regulated by GATA1 protein in zebrafish embryos. Development. 2001;128(12):2341-2350.

67. Finelli P, Pincelli AI, Russo S, et al. Disruption of friend of GATA 2 gene (FOG-2) by a de novo $t(8 ; 10)$ chromosomal translocation is associated with heart defects and gonadal dysgenesis. Clin Genet. 2007;71(3):195-204. doi:10.1111/ j.1399-0004.2007.00752.x

68. Tevosian SG, Deconinck AE, Tanaka M, et al. FOG-2, a cofactor for GATA transcription factors, is essential for heart morphogenesis and development of coronary vessels from epicardium. Cell. 2000;101(7):729-739. doi:10.1016/ s0092-8674(00)80885-5

69. Garnatz AS, Gao Z, Broman M, Martens S, Earley JU, Svensson EC. FOG-2 mediated recruitment of the NuRD complex regulates cardiomyocyte proliferation during heart development. Dev Biol. 2014;395(1):50-61. doi:10.1016/j. ydbio.2014.08.030

70. De Luca A, Sarkozy A, Ferese R, et al. New mutations in ZFPM2/FOG2 gene in tetralogy of Fallot and double outlet right ventricle. Clin Genet. 2011;80(2):184-190. doi:10.1111/j.1399-0004.2010.01523.x

71. Zhang W, Shen L, Deng Z, et al. Novel missense variants of ZFPM2/FOG2 identified in conotruncal heart defect patients do not impair interaction with GATA4. PLoS One. 2014;9(7):e102379. doi:10.1371/journal.pone.0102379

72. Huang X, Niu W, Zhang Z, et al. Identification of novel significant variants of ZFPM2/FOG2 in non-syndromic Tetralogy of Fallot and double outlet right ventricle in a Chinese Han population. Mol Biol Rep. 2014;41(4):26712677. doi:10.1007/s11033-014-3126-5

73. Qian Y, Xiao D, Guo X, et al. Multiple gene variations contributed to congenital heart disease via GATA family transcriptional regulation. J Transl Med. 2017;15(1):69. doi:10.1186/s12967-017-1173-0

74. Sperling S, Grimm CH, Dunkel I, et al. Identification and functional analysis of CITED2 mutations in patients with congenital heart defects. Hum Mutat. 2005;26(6):575-582. doi:10.1002/humu.20262

75. Li Q, Pan H, Guan L, Su D, Ma X. CITED2 mutation links congenital heart defects to dysregulation of the cardiac gene VEGF and PITX2C expression. Biochem Biophys Res Commun. 2012;423(4):895-899. doi:10.1016/j. bbrc.2012.06.099

76. Xu M, Wu X, Li Y, et al. CITED2 mutation and methylation in children with congenital heart disease. J Biomed Sci. 2014;21:7. doi:10.1186/1423-0127-21-7

77. Yin Z, Haynie J, Yang $\mathrm{X}$, et al. The essential role of Cited2, a negative regulator for HIF-1alpha, in heart development and neurulation. Proc Natl Acad Sci U S A. 2002;99(16):10488-10493. doi:10.1073/pnas.162371799

78. Bamforth SD, Braganca J, Farthing CR, et al. Cited 2 controls left-right patterning and heart development through a Nodal-Pitx2c pathway. Nat Genet. 2004;36(11):1189-1196. doi:10.1038/ng1446

79. Yang XF, Wu XY, Li M, et al. [Mutation analysis of Cited2 in patients with congenital heart disease]. Zhonghua Er Ke Za Zhi. 2010;48(4):293-296.

80. Liu Y, Wang F, Wu Y, et al. Variations of CITED2 are associated with congenital heart disease (CHD) in Chinese population. PLoS One. 2014;9(5):e98157. doi:10.1371/ journal.pone.0098157 